\title{
The collective redress action in the Italian legal system
}

\section{Remo Caponi}

Published online: 28 February 2009

(C) ERA 2009

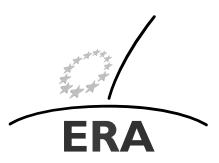

EUROPÄISCHE RECHTSAKADEMIE ACADEMY OF EUROPEAN LAW ACADEMIE DE DROIT EUROPEEN ACCADEMIA DI DIRITTO EUROPEO TRIER - TREVES - TREVIRI

\begin{abstract}
This paper focuses on the key choices of the recent Italian legislation on collective redress actions (azioni collettive risarcitorie). The rules provided for by Article 140-bis codice del consumo (Consumer Code) can be considered only a starting point of a modern regulation in this field (see Sects. 1, 2, 4). Indeed, Art. 140-bis shows several regulatory flaws (see Sect. 3 for the lack of special rules on financial support for collective actions, Sect. 8 for issues relating to the opt-in approach, Sect. 9 for the prerequisites concerning the admissibility of the collective action, Sect. 10 for the publicity of collective actions, Sect. 11 for the contents of the judgment), although it sets out some noteworthy key issues (see Sect. 5 for standing, Sect. 6 for the optin approach, Sect. 12 for collective settlement). The Italian legislation on collective redress actions in the field of consumer protection certainly requires some improvements (see Sect. 7 on a de lege ferenda 'dual system'). However, it can be considered a step forward in the right direction (see Sect. 13).
\end{abstract}

Keywords Collective redress action · Opt-in approach · Opt-out approach · 'Dual system'

\section{Introduction}

This paper focuses on collective redress actions in Italian civil proceedings.

This paper is based on the presentation given by the author at the conference "Collective redress: towards a system of class actions in Europe?". The conference, held in Florence on 30-31 October 2008, was organised by ERA in cooperation with the Fondazione per la formazione forense at the Florence Bar Association and the Giovanni Fabbrini University Center for studies in Civil Justice.

R. Caponi $(\bowtie)$

Faculty of Law, University of Florence, Via delle Pandette, 35, 50137 Firenze, Italy

e-mail: remo.caponi@unifi.it 
Since it is addressed to an European audience, its purpose is especially to outline the basic features and the fundamental choices of the Italian regulation. Therefore this contribution will not deal with details of Italian civil procedure.

From the same standpoint, the following remarks are confined to collective redress actions, and do not refer to collective actions for injunctive relief, where the Italian legislation closely follows the European experience, particularly with regard to consumer protection.

\section{Article 140-bis codice del consumo as a starting point}

Several legislative drafts on collective redress actions had been submitted to the Italian Parliament in recent years. Partly because of remarkable differences between the proposals, these were doomed to failure.

Nevertheless, as a result of an unexpected and fortuitous turn in the parliamentary debate a new provision was passed at the end of 2007. Thus, Art. 140-bis was added to the Consumer Code (codice del consumo, hereinafter: 'cod. cons.').

Since its approval, the provision has shown several regulatory deficiencies, mainly due to its hurried passage. Therefore it can be considered only as a starting point in the regulation of collective redress actions.

The full awareness of these flaws has resulted in the postponement of the entry into force of Art. 140-bis cod. cons. (to the end of June 2009).

However, some noteworthy key issues in the field of collective redress actions have already been highlighted by the new provision.

\section{Funding of collective actions: the crucial flaw}

Before dealing with the fundamental choices of the Italian approach to collective redress actions, a crucial flaw needs to be pointed out: the lack of special rules on financial support for these particular actions.

Although funding is a strategic issue in this matter, ${ }^{1}$ the Italian debate on the point is still at an early stage.

On the other hand, costs and fees are fully governed by traditional general rules. With regard to this, it is however worth noting that as a result of recent developments, contingency fees are no longer prohibited. ${ }^{2}$ Lawyers and clients can agree upon fees depending on the outcome of the proceedings.

\section{Scope of application}

Article 140-bis cod. cons. provides for monetary compensation to groups of consumers in the following cases:

\footnotetext{
${ }^{1}$ See Lindblom, in this issue.

${ }^{2}$ See legge 4 agosto 2006, n. 248. 
(a) breach of contract (only for standard form contracts: Article 1342 civil code);

(b) torts;

(c) unfair commercial practices;

(d) breach of competition law.

The limitation to standard form contracts (a) is clearly unreasonable.

However this problem should be overcome in the new text of the provision.

\section{Standing}

Parties entitled to bring collective redress actions are:

(a) Consumer Associations included in the special Registry held by the Government ${ }^{3}$

(b) unregistered associations provided they are 'adequately representative' of collective interests in a particular case.

The latter provision entitles ad hoc associations to bring actions, i.e. even small associations set up for the sole reason of undertaking legal proceedings.

In practice this legislative choice is not so different from that of granting a standing to each consumer. Indeed, it is not difficult for interested consumers to found an association that acts as a plaintiff on the consumers' behalf (moreover they are not required to transfer their individual claims to the plaintiff).

Granting standing to ad hoc associations is the correct choice for two main reasons.

Firstly, under the scope of application of the collective redress action illegal conduct infringes 'homogeneous individual rights'. ${ }^{4}$ So each consumer is obviously entitled to bring an individual action for monetary compensation. Likewise he can be entitled to set up an association that acts as a plaintiff on his and other consumers' behalf.

Secondly, the standing of ad hoc associations, supported by law firms, promotes 'healthy' competition between registered and unregistered associations, with the result that these are encouraged to improve their activities.

On the other hand, as far as only 'diffuse interests' are concerned, it is reasonable to confine standing to registered consumer associations because only these interests have a collective dimension. Classic examples are cases concerning unfair terms in general conditions of contract, or cases relating to the breach of rules preventing the marketing of hazardous products.

\section{Opt-in approach}

Consumers wishing to benefit from collective redress actions have to inform the plaintiff in writing that they wish to opt in ('adesione').

\footnotetext{
${ }^{3}$ These associations are also entitled to bring collective injunctive actions: see Art. 137 cod. cons.

${ }^{4}$ For this terminology see Pellegrini Grinover [14].
} 
Thus, in the Italian legal system it is up to the consumer to decide whether to be bound or not by the judgment. In other words, an 'opt-in' approach has been chosen instead of the opposite system, adopted for instance in some US class actions, where the class representative raises in court the claims of all the class members, those wishing to be excluded have to opt out.

\section{Opt-in or, de lege ferenda, a 'dual system'?}

As in other European countries, the choice between an opt-in or an opt-out approach is the central issue of the Italian debate on collective redress actions.

There is no need to reassess the pros and cons of the two systems.

It is, however, worth pointing out two aspects that are linked to Italian experience.

Firstly, there is a growing awareness that opt-out is the most suitable system to achieve the goals of collective redress actions.

Secondly, there is a growing awareness that opt out does not clash with the constitutional principles of 'due process', at least in the field of small claims, where the disproportion between the legal costs of proceedings and the economic value of the claims is a deterrent for individual actions.

This creates the option of a 'dual system', where the choice between opt-in and opt-out can be determined by the value of the claims. This choice could be left either case by case to the judge (following the example of Danish law), or based on strict legislative quantification.

Development towards an opt-out approach in the field of small claims is exemplified by a recent Italian court decision .

In a proceeding for injunction, the Tribunale di Roma ordered Sky Italia Pay Tv s.r.l. to reimburse subscribers the amounts already paid for automatic mailing of the new TV programme magazine, since these amounts had been wrongfully claimed in breach of the contractual terms. ${ }^{5}$

In other words, the Court ordered the company to reimburse each subscriber, as, according to Article 140, par. 1, letter (b) cod. cons. this was the correct measure to eliminate the damaging effects of the infringement.

In the case in question, a remedy similar to the results of a US class action was granted.

\section{Issues relating to the opt-in approach}

In the opt-in approach, the judgment can only be invoked by consumers who have joined in the action.

Joining in the action is a two-edged sword: obviously parties are also bound by a judgment that rejects a claim.

Vice versa, consumers that have not joined in the collective action can still take individual action.

${ }^{5}$ See Trib. Roma, 30 aprile 2008, in Foro italiano, 2008, I, 2679. 
The decision to join in an action can also be made during the appeal proceedings.

The Italian rules on opt-in are very 'slender'. Many aspects are controversial, as the following examples illustrate.

The first: the possibility of opting-in up to appeal proceedings is provided for in order to maximise the number of 'class members' joining the action. However, this possibility could produce complications for proceedings. So it would appear more reasonable to impose a short deadline for joining in, for instance a deadline of three months after the publishing of a collective action (see on this point Sect. 10).

The second: the plaintiff bears the cost of litigation. One way to contribute to the financing of actions is to ask consumers who have joined in to pay a fee, based on the value of their claim. However, the lack of legislative rules makes this possibility controversial.

\section{9 'Leave' of the action}

The admissibility of a collective redress action is subject to a preliminary evaluation. The 'leave' is to be denied when:

(a) the claim has no real prospect of success;

(b) there are conflicting interests between the plaintiff and the 'class members'; or

(c) a collective interest deserving protection by collective redress action fails.

It is worth noting that it is still controversial what 'collective interest deserving protection' actually means.

The broad terminology may include the conditions of 'numerosity', 'commonality' and 'typicality', such as those established as prerequisites in Rule 23 (a) of the Federal Rules of Civil Procedure.

Moreover, it is controversial whether the requirement of 'adequacy of representation' of the ad hoc associations has to be considered in connection with the assessment on 'collective interest deserving protection'.

An interpretation based on the literal meaning could lead to a negative answer. Nevertheless, issues related to procedural efficiency, as well as comparative arguments, suggest the opposite conclusion. Thus, actions brought by inadequately representative ad hoc associations should be declared inadmissible.

\section{Publishing the action}

If the action is admissible, the judge orders a 'suitable' form of publishing the collective action. The costs are borne by the plaintiff.

Although the need to publicise the pending collective redress action has been accepted from the very early stages as necessary to inform concerned parties, it is a very dangerous tool. Indeed, it could seriously damage the image of the defendant.

The Italian law disregards this problem.

Legislative provisions strictly prescribing a suitable form of publicity according to concerned interests should be introduced. 


\section{Contents of the judgment}

Court proceedings consists of two fundamental stages. The first aims at ascertaining the right to compensation.

At the end of this stage the judge:

(a) determines the criteria for quantifying the amount of compensation due to each class member, or

(b) sets a minimum amount to be paid to each class member, if evidence so allows.

\section{Collective settlement}

The second stage aims at quantifying the amount due to each class member in a collective settlement before an ad hoc commission or in an individual action, brought by class members who do not wish to join the collective settlement.

\section{Concluding remarks}

Italian legislation on collective redress actions in the field of consumer protection requires some improvements. However, it can be considered a step forward in the right direction.

Firstly, it grants effective access to justice for small claims, in that at the collective redress action provided for by Article 140-bis cod. cons. reduces litigation costs. Thus it overcomes the problem of disproportion between the legal costs of proceedings and the low value of individual claims, and it also provides for an effective remedy.

Secondly, collective redress action can provide compensation for harms caused to many consumers.

Besides these aspects, the new remedy serves another important purpose: it acts as a deterrent for unlawful conducts. In this regard, collective redress actions tend to leverage private litigation in order to serve a particular policy or regulatory interest (private enforcement).

Thirdly, collective redress actions improve judicial efficiency when there are questions of law or fact common to the claims of the group members and the concerned consumers are so numerous that the involvement of all of them is impractical.

\section{References}

1. Bove, M.: L'oggetto del processo 'collettivo': dall'azione inibitoria all'azione risarcitoria (articoli 140 e 140-bis cod. cons.). In: Il Giusto Processo Civile (2008)

2. Briguglio, A.: L'azione collettiva risarcitoria. Torino (2008)

3. Caponi, R.: Litisconsorzio 'aggregato'. L'azione risarcitoria in forma collettiva dei consumatori. In: Rivista Trimestrale di Diritto e Procedura Civile, pp. 819-852 (2008)

4. Caponi, R.: Azioni collettive: interessi protetti e modelli processuali di tutela. In: Rivista di Diritto Processuale, pp. 1205-1225 (2008)

5. Caponi, R.: Variabilità dell'oggetto del processo (nell'azione collettiva risarcitoria). In: Rivista di Diritto Processuale (2009) (forthcoming) 
6. Carratta, A.: L'azione collettiva risarcitoria e restitutoria: presupposti ed effetti. In: Rivista di Diritto Processuale, pp. 723-744 (2008)

7. Chiarloni, S.: Il nuovo art. 140-bis del codice del consumo: azione di classe o azione collettiva? In: Analisi Giuridica dell'Economia (2008)

8. Consolo, Bona, Buzzelli: Obiettivo class action: 1'azione risarcitoria collettiva. Milano (2008)

9. Dondi, A.: Of some drawbacks in the italian road to class actions. In: ZZP-Int., 2008

10. Giussani, A.: Azioni collettive risarcitorie nel processo civile. Bologna (2008)

11. Giussani, A.: L'azione collettiva risarcitoria nell'art. 140-bis cod. cons. In: Rivista di Diritto Processuale, pp. 1227-1248 (2008)

12. Menchini, S.: La nuova azione collettiva risarcitoria e restitutoria. In: Il Giusto Processo Civivile (2008)

13. Pagni, I.: I rapporti tra l'azione inibitoria e l'azione risarcitoria. In: Analisi Giuridica dell'Economia (2008)

14. Pellegrini, G.A.: New trends in standing and res iudicata in collective suits, general report civil law. In: XIII International Congress of Procedural Law, Salvador/Bahia, 16-22 September 2007

15. Ruffini, G.: Legittimazione ad agire, adesione ed intervento nella nuova normativa sulle azioni collettive risarcitorie e restitutorie di cui all'art. 140-bis del codice del consumo. In: Rivista di Diritto Processuale, pp. 707-722 (2008) 